$\mathbf{R}_{\text {ESEARCH }} \mathbf{P}_{\text {APER }} \longrightarrow$ FOOD SCIENCE e ISSN-2230-9403 $\square$ Visit us :
www.researchjournal.co.in

Volume 9 | Issue $1 \mid$ April, 2018 | 201-204

DOI : 10.15740/HAS/FSRJ/9.1/201-204

\title{
Assessment of therapeutic effect of moringa fortified products
}

\author{
Archana Kumari and $J_{\text {itendra }}$ Singh
}

\begin{abstract}
Moringa oleifera has very high nutritional properties that would be useful as a food supplement especially in those relegated communities. Besides its nutritional and medicinal applications Moringa oleifera is very useful as an alley crop in the agro-forestry industry. It is useful not only for human beings but also for animals and also in various industrial applications. It has been processed into a medicine it contains acetone which can be prepared into herbal formulation which is an effective anti-malaria bio agent. Such trees have the potential to be a source of new drugs. It is also an effective water clarifier using the seed thus providing millions of people with clean drinking water. This study indicates that the developed products of biscuit with moringa can be easily prepared under optimized condition. The various parameters such as moisture, crude protein, iron, total ash and calcium were analyzed. The sensory evaluation of products on all attributes (appearance, taste, flavour, texture, colour and overall acceptability) was found in biscuit which was highly acceptable, due to Bajra flour, wheat flour, Moringa oleifera leaves, milk cream and butter. The analysed nutritional content (protein, iron, calcium) of developed products concluded that nutritive value of moringa was highest then other developed products. The benefits for the treatment or prevention of joint pain disease or infection that may accrue from taking moringa fortified biscuits daily. In this study we determined the effect of a biscuit fortified with moringa leaves on the vitamins and minerals status of women between age group 35 to 50 and above living in an area with a known prevalence of diseases.
\end{abstract}

Key Words : Moringa oleifera, Nutritional value, Therapeutic effect

How to cite this article : Kumari, Archana and Singh, Jitendra (2018). Assessment of therapeutic effect of moringa fortified products. Food Sci. Res. J., 9(1): 201-204, DOI : 10.15740/HAS/FSRJ/9.1/201-204. 